Studia nad Autorytaryzmem i Totalitaryzmem 43, nr 3

Wrocław 2021

https://doi.org/10.19195/2300-7249.43.3.6

\author{
KRZYSZTOF KUŁAK \\ ORCID 0000-0001-6785-2468 \\ Uniwersytet Wrocławski \\ krzysztof.kulak@uwr.edu.pl
}

\title{
Skazane na zapomnienie — prawo handlowe w PRL
}

Słowa kluczowe: prawo handlowe, kodeks handlowy, kodeks cywilny, jedność prawa prywatnego, gospodarka, PRL.

\section{CONDEMNED TO OBLIVION: COMMERCIAL LAW \\ IN THE POLISH PEOPLE'S REPUBLIC}

\begin{abstract}
The post-war history of Polish commercial law is not a frequent subject of interest in the literature. Historical reflection is usually limited to indicating that the civil code entering into force on 1 January 1965 and, on the same day, the repeal of the pre-war commercial code from 1934 formally ended the era of Polish private law's duality - the coexistence of two equal branches of law: civil law, regulating common relations, and commercial law, regulating economic relations. However, it was the last symbolic chord in the history of commercial law during the communist period. In fact, it had been extinguished several years earlier and replaced by a socialist substitute in the form of economic law, intended to regulate the centrally planned, socialist trading, in which there was no space for individual economic activity. The article discusses the mechanism of dismantling commercial law in the political and economical order of the totalitarian state, which Poland became after the Second World War. This mechanism was implemented not on the normative level, by repealing the norms of commercial law, but on the factual one, by eliminating - through administrative, fiscal, and penal pressure methods - addressees of commercial law (already existing and potential entrepreneurs) and taking them away, e.g. by nationalizing the most essential components of their enterprises. In this way, the necessary (personal and property) background of commercial law was destroyed, making its norms irrelevant. Thus, commercial law was condemned to a dozen or so years of non-existence and oblivion before the legislator decided to make a formal decision, which was to repeal most provisions of the commercial code. Only those regulations remained in force that were needed by the communist authorities, e.g. to conduct foreign trade. The effects of several-decades-long systemic non-existence of commercial law are still noticeable today. Despite
\end{abstract}


the systemic transformation in 1989 and the return of the Polish economy to free market rules, Polish commercial law - relegated to the role of a specialized discipline of civil law and formally distinguished only for research and teaching activities — has not yet regained its rank as an independent branch of private law.

Keywords: commercial law, commercial code, civil code, unity of private law, economy, Polish People's Republic.

\section{I}

Historia polskiego prawa handlowego, choć niedługa, jest dość ciekawa ${ }^{1}$. Spadkiem po okresie zaborów była niefunkcjonalna i niemożliwa do utrzymania mozaika kodeksów handlowych: francuskiego, austriackiego i niemieckiego oraz prawa rosyjskiego ${ }^{2}$. Dwudziestolecie międzywojenne przyniosło wprawdzie unifikację i kodyfikację ${ }^{3}$ tego działu prawa w postaci kodeksu handlowego ${ }^{4}$ z 1934 roku, ale osiągnięcie to zostało wkrótce przekreślone w wyniku wybuchu drugiej wojny światowej i zmian politycznych, które nastąpiły wraz z jej zakończeniem.

Problematyka historyczna polskiego prawa handlowego przez lata nie była przedmiotem większego zainteresowania piśmiennictwa ${ }^{5}$. Jest to poniekąd zrozumiałe. W okresie PRL potrzeby rozprawiania o prawie handlowym — również

${ }^{1}$ Zob. J. Frąckowiak, Osiemdziesiąt lat polskiego prawa handlowego - wzloty, upadki oraz mozolna reaktywacja, „Przegląd Prawa i Administracji” 2015, nr 101, s. 46 n.; L. Górnicki, Pogranicza systemów prawnych, $w$ szczególności pozaborowych, $w$ pracach nad kodyfikacjami prawa cywilnego i handlowego w II RP, „Prawo” 324, 2017, s. 129 n.

2 Zob. Encyklopedia praktyki prawniczej $w$ dziesięciu tomach, cz. 1. Prawo handlowe, t. 1, red. A. Szczygielski, Warszawa 1938, s. 12-14; L. Górnicki, Pogranicza ..., s. 149-150.

${ }^{3}$ Zarówno unifikacja, jak i kodyfikacja nie miały charakteru zupełnego, zob. Encyklopedia praktyki..., s. 17; J. Sułkowski, Polski kodeks handlowy, „Ruch Prawniczy, Ekonomiczny i Socjologiczny" 1934, nr 2, s. 95-96; L. Górnicki, Przewodnie konstrukcje i pojęcia Kodeksu handlowego z 1934 roku, „Przegląd Prawa i Administracji” 2015, nr 101, s. 67-68. Niepoddane unifikacji, a w konsekwencji poza kodeksem handlowym (choć w założeniu czasowo) pozostały między innymi przepisy prawa ubezpieczeniowego, prawa handlowego morskiego i prawa rzecznego, będące wciąż regulacjami dzielnicowymi. Z założenia poza kodeksem, w formie odrębnych aktów prawnych, miało pozostać na przykład prawo upadłościowe, prawo układowe, przepisy regulujące zwalczanie nieuczciwej konkurencji, prawo wekslowe i prawo czekowe. Pośrednio zdaje się wskazywać na to J. Wasilkowski, Zagadnienia kodyfikacji polskiego prawa cywilnego, „Nowe Drogi” 1960, nr 11, s. 28.

${ }^{4}$ Rozporządzenie Prezydenta Rzeczypospolitej z dnia 27 czerwca 1934 r. - Kodeks handlowy, Dz.U. Nr 57, poz. 502 (dalej: k.h.).

${ }^{5}$ Oprócz opracowań powołanych w przypisie 1 zob. Prawo handlowe i gospodarcze II Rzeczypospolitej, red. R. Jastrzębski, Warszawa 2019; L. Górnicki, Organizacyjne zagadnienia kodyfikacji prawa handlowego w Komisji Kodyfikacyjnej RP (1919-1939), „Prawo” 2003, nr 285, s. 261-288; idem, Przewodnie..., s. 63 n.; idem, Komisja Kodyfikacyjna II RP: pozycja ustrojowa, struktura organizacyjna, podejmowanie decyzji, „Prawo” 328, 2019, s. 109 n.; idem, Prace Komisji Kodyfikacyjnej RP nad kodeksem handlowym z 1934 r.: organizacja i koncepcja kodyfikacyjna, „Przegląd Prawa Handlowego” 2015, nr 8, s. 50 n. 
na płaszczyźnie historycznej — po prostu nie było, ponieważ faktycznie nie funkcjonowało samo prawo handlowe. Nagłe przestawienie ustroju polityczno-gospodarczego na tory gospodarki wolnorynkowej i żywiołowy rozwój przedsiębiorczości po 1989 roku dało wprawdzie impuls do równie żywiołowego ${ }^{6}$ odrodzenia się prawa handlowego (choć w odmienionej już treści, formie i zakresie), ale zarazem ujawniło liczne, wymagające pilnego rozwiązania problemy natury praktycznej. Siłą rzeczy uwaga i wysiłek twórczy kształtującego się na nowo, po latach przerwy, grona komercjalistów były ukierunkowane na bieżące zagadnienia istotne dla praktyki obrotu. Czas na refleksję uwzględniającą historyczne losy prawa handlowego nastał, kiedy obrót gospodarczy okrzepł już na wolnorynkowych fundamentach zabezpieczonych przez zasadniczo stabilną regulację prawną, a kolejne pokolenie komercjalistów, spoglądając wstecz i przed siebie, zastanawia się nad miejscem prawa handlowego ${ }^{7}$.

Interesujący rys historyczny polskiego prawa handlowego przedstawił J. Frąckowiak, który jego historię podzielił na trzy okresy, opatrując je wymownymi tytułami: lata 1934-1939 — „świetny początek”, lata 1945-1988 — „przerwa w obowiązywaniu” oraz czas po 1989 roku — ,powolna i mozolna reaktywacja prawa handlowego" 8 .

Niniejsze opracowanie skupia się na okresie drugim i okolicznościach, w których doszło do systemowego wygaszenia prawa handlowego stworzonego przed drugą wojną światową. Chociaż z dzisiejszej perspektywy czas tłamszenia prawa handlowego w PRL może wydawać się zamkniętym już (choć przydługim) rozdziałem, jego skutki widoczne są do dziś i wiele wskazuje na to, że jeszcze długo będą one wpływać na sposób postrzegania i miejsce prawa handlowego w systemie prawa.

Zniesienie prawa handlowego w PRL jest zwykle łączone z wejściem w życie obowiązującego do dziś kodeksu cywilnego9. Cezura ta wyznacza kres nie tylko prawa handlowego w jego przedwojennym kształcie, lecz także istniejącego w II RP dualistycznego ujęcia prawa prywatnego, zakładającego współistnienie obok siebie dwóch równorzędnych gałęzi prawa prywatnego w postaci prawa cywilnego i prawa handlowego właśnie. Bliższe spojrzenie na kilkunastoletni okres, przypadający po 1945 roku, w którym przygotowywano kolejne projekty kodeksu cywilnego, w tym na towarzyszące tym pracom wypowiedzi osób w nie zaangażowanych, pozwala jednak uchwycić mechanizm i rzeczywisty czas wygaszenia prawa handlowego i wyrugowania go ze świadomości nie tylko osób tworzących i stosujących prawo, ale przede wszystkim jego adresatów.

${ }^{6}$ O owej żywiołowości mówi obrazowo A. Kappes, [w:] D. Niedzielska-Jakubczyk, Prawo handlowe przetrwato nawet socjalizm [wywiad z prof. A. Kappesem], „Gazeta Prawna” 29.04.2015.

7 Zob. „Przegląd Prawa i Administracji” 121, 2020, i zamieszczone tam opracowania.

8 J. Frąckowiak, op. cit., s. 45 n.

9 Ustawa z dnia 23 kwietnia 1964 r. — Kodeks cywilny, Dz.U. z 2020 r. poz. 1740 (dalej: k.c.). 


\section{II}

Z dniem 1 stycznia 1965 roku, wraz z wejściem w życie kodeksu cywilnego, na mocy art. VI $\S 1$ przepisów wprowadzających kodeks cywilny ${ }^{10}$ uchylono kodeks handlowy i przepisy wprowadzające kodeks handlowy ${ }^{11}$, pozostawiając w mocy jedynie przepisy dotyczące spółki jawnej, spółki z ograniczoną odpowiedzialnością i spółki akcyjnej oraz odnoszące się do nich przepisy o firmie, prokurze i rejestrze handlowym.

Obowiązujący od 1 lipca 1934 roku kodeks handlowy tworzył trzon prawa handlowego. Jego przyjęcie nie tylko w znacznym stopniu ujednoliciło regulację obrotu gospodarczego, ale także, na wzór większości ówczesnych obcych porządków prawnych, usankcjonowało dualizm prawa prywatnego. Oprócz prawa cywilnego regulującego obrót powszechny na obszarze całego państwa obowiązywało prawo handlowe regulujące obrót gospodarczy i organizację jego uczestników (kupców ${ }^{12}$ ). Przygotowany przez wybitnych prawników - praktyków i teoretyków, którzy zawodowe i naukowe szlify zdobywali pod rządami różnych porządków prawnych - był aktem nowoczesnym zarówno pod względem treści, jak i formy. Wzorowany na powszechnie docenianym i sprawdzonym już wtedy w praktyce niemieckim kodeksie handlowym (HGB) ${ }^{13}$ z 1897 roku, zawiera1 też własne, oryginalne i unowocześnione względem tego ostatniego rozwiązania, a jego walory zostały dostrzeżone wkrótce po jego przyjęciu i są podkreślane do dziś ${ }^{14}$. Choć przyjęty w okresie, w którym państwo polskie zmierzało już ku rządom autorytarnym, stanowił konstrukcję politycznie neutralną, właściwą państwom hołdującym wolnorynkowym zasadom obrotu gospodarczego.

Wybuch drugiej wojny światowej brutalnie przerwał funkcjonowanie państwa, obrót gospodarczy i obowiązywanie polskiego prawa, w tym kodeksu handlowego. Powojenne próby podnoszenia $\mathrm{z}$ gruzów lub zastoju przedsiębiorstw przez ich przedwojennych właścicieli przerwała wkrótce nacjonalizacja przemysłu

${ }^{10}$ Ustawa z dnia 23 kwietnia 1964 r. — Przepisy wprowadzające kodeks cywilny, Dz.U. Nr 16, poz. 94.

11 Rozporządzenie Prezydenta Rzeczypospolitej z dnia 27 czerwca 1934 r. - Przepisy wprowadzające Kodeks handlowy, Dz.U. Nr 57, poz. 503.

12 Pojęcie to zostało zdefiniowane w art. $2 \S 1$ k.h., zgodnie z którym kupcem był każdy, kto we własnym imieniu prowadził przedsiębiorstwo zarobkowe. Kategoria kupca, zgodnie z przyjętą podmiotową koncepcją prawa handlowego, tworzyła podstawę wyróżnienia jego norm spośród ogółu norm prywatnoprawnych (tak zwane kryterium subiektywne).

13 Przyczyny obrania systemu germańskiego za wzór kodeksu handlowego omawia L. Górnicki, Przewodnie..., s. 73-74 i 88.

14 Zob. Encyklopedia praktyki..., s. 18-20; J. Bardach, B. Leśnodorski, M. Pietrzak, Historia ustroju i prawa polskiego, Warszawa 2008, s. 584; S. Sołtysiński, Kodeks spółek handlowych. (Podstawowe założenia), „Państwo i Prawo” 2000, nr 11, s. 4; L. Górnicki, Przewodnie..., s. 63, 66-67, 89-90. 
i handlu z 1946 roku $^{15}$, tak zwana bitwa o hande ${ }^{16}$ z lat 1947-1949, a także, choć w mniejszej skali, nieco wcześniejsza „reforma” rolna $^{17}$ i nacjonalizacja gruntów warszawskich (dekret Bieruta) ${ }^{18}$, skutkujące ostatecznie pozbawieniem większości przedwojennych kupców ich przedsiębiorstw lub najistotniejszych składników tych przedsiębiorstw ${ }^{19}$. Działaniom tym towarzyszyło wzmożenie, od 1949 roku, działalności legislacyjnej w zakresie stosunków obrotu uspołecznionego ${ }^{20}$. W krystalizujących się warunkach nowego ustroju polityczno-gospodarczego, coraz trudniej tolerującego własność prywatną i aktywność gospodarczą jednostek, prawo handlowe coraz mniej przystawało do nowej rzeczywistości. Interesująco rysuje się jednak stosunek władzy ludowej do tak ideologicznie obcej jej regulacji. Chociaż w ustroju, w którym dominująca stała się własność państwowa, a gospodarka funkcjonowała na podstawie metody nakazowo-rozdzielczej, prawo handlowe $\mathrm{w}$ dotychczasowej postaci nie miało racji bytu, nowa władza oficjalnie go nie zwalczała. Należałoby przy tym wspomnieć o dwóch polach, na których problem prawa handlowego występowat: wewnętrznym (krajowym) i zewnętrznym, związanym $\mathrm{z}$ handlem zagranicznym, objętym monopolem państwa.

W tym pierwszym przypadku punkt ciężkości zmian w omawianym zakresie był od początku przesunięty z płaszczyzny normatywnej w sferę faktów. Znacjonalizowanie przedsiębiorstw przedwojennych kupców w większości pozbawiło ich faktycznej zdolności do dalszego prowadzenia działalności. Efekt ten został wzmocniony utrudnieniami wprowadzonymi przez państwo $\mathrm{w}$ ramach

15 Zob. ustawa z dnia 3 stycznia 1946 r. o przejęciu na własność Państwa podstawowych gałęzi gospodarki narodowej (Dz.U. Nr 3, poz. 17), zmieniona dekretem z dnia 20 grudnia 1946 r. o zmianie ustawy z dnia 3 stycznia 1946 r. o przejęciu na własność Państwa podstawowych gałęzi gospodarki narodowej (Dz.U. Nr 72, poz. 394).

${ }^{16}$ Określenie to - użyte na plenum KC PPR 13 kwietnia 1947 r. przez ówczesnego ministra przemysłu i handlu Hilarego Minca — odnosi się do zrealizowanego przez państwo w latach 19471949 programu eliminowania prywatnej przedsiębiorczości w zakresie handlu i usług oraz zastępowania jej jednostkami państwowymi. Nastąpiło to przede wszystkim na podstawie trzech ustaw z 2 czerwca 1947 r.: o zwalczaniu drożyzny i nadmiernych zysków w obrocie handlowym (Dz.U. $\mathrm{Nr} 43$, poz. 218), o obywatelskich komisjach podatkowych i lustratorach społecznych (Dz.U. Nr 43, poz. 219), o zezwoleniach na prowadzenie przedsiębiorstw handlowych i zawodowe wykonywanie czynności handlowych (Dz.U. Nr 43, poz. 220), oraz dekretu z dnia 28 października 1947 r. w sprawie obowiązku zawiadomienia o prowadzeniu przemysłu i wykonywaniu niektórych zajęć zarobkowych (Dz.U. Nr 66, poz. 403). Realizacji tego założenia służył również wcześniejszy dekret z dnia 16 listopada 1945 r. o utworzeniu i zakresie działania Komisji Specjalnej do walki z Nadużyciami i Szkodnictwem Gospodarczym (Dz.U. z 1950 r. Nr 41, poz. 374).

17 Zob. dekret Polskiego Komitetu Wyzwolenia Narodowego z dnia 6 września 1944 r. o przeprowadzeniu reformy rolnej, Dz.U. z 1945 r. Nr 3, poz. 13.

18 Zob. dekret z dnia 26 października 1945 r. o własności i użytkowaniu gruntów na obszarze m. st. Warszawy, Dz.U. Nr 50, poz. 279. Regulacja ta nie była zorientowana na wywoływanie bezpośrednich następstw w dziedzinie gospodarki, choć, co zrozumiałe, skutki takie powodowała.

19 Zob. A. Kappes, op. cit.

20 W. Czachórski, Przebieg prac nad kodyfikacja prawa cywilnego PRL, ,Studia Prawnicze” 1970, nr 26-27, s. 10. 
walki z sektorem prywatnym, w tym z rzemieślnikami i wykonującymi wolne zawody (podatek domiarowy, koncesjonowanie kolejnych rodzajów działalności, obostrzenia w handlu hurtowym, drastyczne sankcje karne za spekulanctwo itp.). Wszystko to działo się przy formalnym utrzymaniu norm prawa handlowego $\mathrm{w}$ mocy $\mathrm{w}$ ich dotychczasowej postaci ${ }^{21}$. Mechanizm ten polegał więc na faktycznym wyeliminowaniu z obrotu prawnego (gospodarczego) grupy osób będących przedwojennymi kupcami lub dopiero chcących podjąć aktywność gospodarczą na własny rachunek przez pozbawienie ich majątku niezbędnego do prowadzenia działalności lub kreowanie innego rodzaju barier zniechęcających lub odstraszających o charakterze administracyjnym, podatkowym czy karnym ${ }^{22}$. W warunkach wewnętrznych doprowadzono więc $\mathrm{w}$ istocie do wyeliminowania dotychczasowych i potencjalnych adresatów norm prawa handlowego - kupców, którzy jego przepisy mieliby w praktyce obrotu stosować i którzy jego przepisom mieliby podlegać ${ }^{23}$. W braku osób, którym mogłyby służyć, normy dotychczasowego prawa handlowego stały się regulacją martwą (nie zmieniła tego, późniejsza już, datowana na czas odwilży 1956 roku, epizodyczna koncepcja spółek mieszanych, państwowo-prywatnych, które miały umożliwić gospodarcze zaangażowanie osób prywatnych ${ }^{24}$ ).

Faktycznemu eliminowaniu adresatów prawa handlowego z obrotu nie towarzyszyły jednak odgórne rozstrzygnięcia formalne w tym zakresie. Władza nie zdecydowała się na ustawowe rozwiązanie (likwidację) i wykreślenie z rejestru handlowego przedwojennych spółek prawa handlowego, nawet tych, które - czy to ze względu na pozbawienie ich przedsiębiorstwa (nacjonalizacja nawet całego majątku spółki nie skutkowała jej rozwiązaniem), czy wojenne lub powojenne losy ich wspólników — zaprzestały prowadzenia działalności. W okresie późniejszym, bo w 1959 roku, sprawa ta była przedmiotem analizy Ministerstwa Sprawiedliwości, które - miejscami cynicznie — wskazywało na wiele argumentów mających przemawiać przeciwko takiemu rozwiązaniu (między innymi za nieuzasadnione społecznie uznano dalsze, uwzględniwszy przeprowadzoną już nacjonalizację mienia, odbieranie wierzycielom spółek możliwości zaspokojenia

21 Nie licząc dwóch, wymuszonych względami technicznymi, powojennych nowelizacji kodeksu handlowego, przeprowadzonych na mocy dekretu z dnia 11 października 1946 r. — Przepisy wprowadzające prawo rzeczowe i prawo o księgach wieczystych (Dz.U. Nr 57, poz. 321) oraz ustawy — Przepisy wprowadzające przepisy ogólne prawa cywilnego z dnia 18 lipca 1950 r. (Dz.U. Nr 34, poz. 312).

${ }^{22}$ Zob. akty prawne przytoczone w przypisie 15 oraz wydane na ich podstawie rozporządzenia wykonawcze.

23 Zob. A. Kappes, op. cit.

${ }^{24}$ Zob. więcej Z. Żabiński, Cywilno-prawne problemy spólek państwowo-prywatnych, „Przegląd Ustawodawstwa Gospodarczego" 1958, nr 6, s. 214, który podaje, że po wprowadzeniu ograniczeń w zawiązywaniu tego typu spółek, w 1958 r. było ich dwanaście; oraz P. Kowalski, O zaniechanej akcji likwidacji przedwojennych spótek prawa handlowego w Polsce Ludowej, „Miscellanea Historico-Iuridica” 2013, nr 12, s. 425. 
ich wierzytelności, a wspólnikom - możliwości realizacji uprawnienia do nadwyżki polikwidacyjnej; za „ciągle nierozwiązaną” uznano sprawę odszkodowań należnych na podstawie ustawy nacjonalizacyjnej, do których prawa wchodzily do majątków spółek, uniemożliwiając z kolei ich upłynnienie; wskazano na przeciążenie sądów wieczystoksięgowych, które przejęły prowadzenie rejestrów handlowych; wreszcie obawiano się trudności z egzekwowaniem przysługujących spółkom wierzytelności zagranicznych czy konieczności transferu upłynnionego majątku rozwiązywanych spółek na Zachód ze względu na zaangażowanie kapitału zagranicznego $\mathrm{w}$ te spółki, a w dalszej kolejności — w razie prób ograniczania tych transferów za pomocą prawa dewizowego - utrudnienia stosunków handlowych PRL $\mathrm{z}$ zagranicą ${ }^{25}$ ). Za zasadne uznano jedynie rozwiązanie $\mathrm{z}$ urzędu spółek akcyjnych i spółek z o.o. w przypadkach wyjątkowych, uzasadnionych „niepożądaną działalnością spółki”"26. Znamienne okazuje się ostatnie zdanie jednego z dotyczących omawianej kwestii dokumentów powstałych w Ministerstwie Sprawiedliwości: „Stanowczo lepiej jest spraw tych nie poruszać, tym bardziej, że cała projektowana akcja nie przyniesie zapewne żadnych efektywnych korzyści, a spowodować może wiele kłopotów i kosztów"27. Przedwojenne spółki handlowe, tworzące trzon stanu kupieckiego, były więc dla władzy pewnym problemem, który postanowiła ona jednak przeczekać, marginalizując je i prowadząc ich demontaż, używając innych narzędzi niż te wywodzące się z prawa handlowego.

Trudno dziś o jednoznaczną odpowiedź, czy przeprowadzana w ten sposób degradacja prawa handlowego była precyzyjnie zaplanowanym działaniem, czy raczej wypadkową posunięć nieskładających się na ustaloną z góry strategię. Niemniej utrzymanie $\mathrm{w}$ mocy, $\mathrm{w}$ zasadzie bez zmian, przepisów prawa handlowego, z kodeksem handlowym na czele, i nieingerowanie w formalny byt prawny przedwojennych spółek stało się listkiem figowym pozwalającym władzy ludowej na przysłonienie, również na potrzeby kreowania określonego obrazu Polski na forum zagranicznym (przynajmniej przed zaostrzeniem kursu politycznego), jej prawdziwych, wstydliwych poczynań w odniesieniu do prywatnego sektora gospodarki.

Problem prawa handlowego ujawnił się też na wspomnianej już wcześniej płaszczyźnie zagranicznych stosunków handlowych. Na potrzeby tych relacji, opierając się na przedwojennym kodeksie handlowym, władza stworzyła i utrzymywała pewną grupę spółek kapitałowych (przede wszystkim spółek z o.o.) z całkowitym udziałem Skarbu Państwa, których zadaniem była obsługa objętego państwowym monopolem obrotu gospodarczego z krajami o gospodarce

25 Pismo dyrektora Departamentu Ustawodawczego Ministerstwa Sprawiedliwości z 9 lipca 1959 r., za: P. Kowalski, op. cit., s. 431-433.

26 Ibidem.

27 Pismo dyrektora departamentu w Ministerstwie Sprawiedliwości z 30 czerwca 1959 r., za: P. Kowalski, op. cit., s. 434. 
wolnorynkowej ${ }^{28}$. Choć formalnie były to spółki prawa handlowego, w istocie pozostawały państwowymi osobami prawnymi i... jednostkami gospodarki uspołecznionej ${ }^{29}$. Zapewniały one jednak możliwość wystawienia w relacjach handlu zagranicznego jako reprezentanta interesów państwa polskiego jednostki organizacyjnej o tradycyjnej formie organizacyjnoprawnej i zasadach działania znanych partnerom zagranicznym ${ }^{30}$. Wymuszone tymi okolicznościami i jednowładztwem Skarbu Państwa będącego jedynym wspólnikiem (akcjonariuszem) tych spółek zakres stosowania i praktyczne znacznie przepisów prawa handlowego dotyczących ich funkcjonowania były istotnie ograniczone ${ }^{31}$. W piśmiennictwie wskazano jednak, że konieczność utrzymania tego rodzaju spółek na potrzeby handlu zagranicznego uchroniła kodeks handlowy przed formalnym uchyleniem w cało$\mathrm{ści}^{32}$. W świetle oficjalnych wypowiedzi twórców kodeksu cywilnego na temat kodeksu handlowego wątpliwości może natomiast budzić to, czy zachowanie przepisów kodeksu handlowego o spółkach handlowych, właśnie pod pretekstem wymogów handlu zagranicznego, było wyrazem ich sprytu i planowego działania (a więc fortelu zastosowanego względem władzy), które z kolei umożliwiło szybki powrót spółek handlowych do rzeczywistości gospodarczej po 1989 roku $^{33}$ W każdym razie o ile w sferze wewnętrznej władza przepisy prawa handlowego zmarginalizowała i skazała na zapomnienie, o tyle w sferze zewnętrznej w sposób zinstrumentalizowany milcząco tolerowała jego dalsze obowiązywanie w zakresie niezbędnym do osiągnięcia swoich celów.

Omówione okoliczności dowodzą, że wygaszenie prawa handlowego nastąpiło na płaszczyźnie pozaprawnej, bez ostentacyjnego uchylania kodeksu handlowego, na długo przed uchwaleniem i wejściem w życie kodeksu cywilnego. Prawo handlowe pozbawione swoich koniecznych aktorów w osobie kupców stało się zbiorem przepisów praktycznie martwych i zostało skazane na powolną agonię. Uchylenie kodeksu handlowego wraz z wejściem w życie kodeksu cywilnego jedynie formalnie przypieczętowało to, ,co było już faktem - prawo handlowe w dawnej postaci przestało istnieć" 34 .

28 Zob. więcej P. Kowalski, op. cit., s. 424-425; P. Nazaruk, Analiza historyczno-prawna rozwoju instytucji spótki z ograniczona odpowiedzialnościa w Europie Zachodniej i Polsce, „Studia Gdańskie. Wizje i rzeczywistość" 2014, nr 11, s. 397.

29 S. Grzybowski, [w:] System prawa cywilnego, t. 1. Część ogólna, red. S. Grzybowski, Wrocław 1974, s. 397.

30 A. Kappes, op. cit.

31 S. Grzybowski, [w:] System prawa cywilnego, t. 1, s. 397-398.

32 A. Bielecki, D. Szpoper, Rys historyczny rozwoju instytucji spótki z ograniczona odpowiedzialnościa na ziemiach polskich na tle wybranych rozwiazań prawnych innych państw europejskich $w X X$ w., [w:] A. Bielecki, D. Szpoper, I. Zdanowski, Przyczynki do historii prawa, Sopot 2000, s. 9293; K. Kruczalak, Prawo handlowe. Zarys wykładu, Warszawa 2001, s. 153; zob. też Komisja Kodyfikacyjna przy Ministrze Sprawiedliwości, Projekt..., s. 198 i lakoniczne uzasadnienie tej kwestii.

33 Zob. J. Frąckowiak, op. cit., s. 52-53.

34 Ibidem, s. 52. Zob. też M. Tarska, Jedność prawa cywilnego a regulacja prawna spółek handlowych - zagadnienia wybrane, „Acta Iuris Stetinensis” 2019, nr 3, s. 194, która mówi o „propagandowym uchyleniu" kodeksu handlowego; A. Kappes, op. cit. 
Znamiennie jest, że w toku prac nad kodeksem cywilnym problem prawa handlowego w zasadzie nie istniał w świadomości jego twórców ${ }^{35}$ (nie występował on też na wcześniejszym etapie unifikacji prawa cywilnego z lat 1945$1946^{36}$ ). O kodeksie handlowym wspominano jedynie sporadycznie — jako znak czasów, już bez przedwojennej estymy — wskazując, że jego regulacja stała się nieprzydatna $\mathrm{w}$ ówczesnym ustroju społeczno-gospodarczym ${ }^{37}$ albo że wybrane jego przepisy przejęto - modyfikując je względem pierwowzoru - do projektu kodeksu cywilnego ${ }^{38}$. Wydaje się więc, że pogodzono się z naturalnym w ówczesnych warunkach faktem obumarcia nie tylko samej regulacji, lecz także koncepcji prawa handlowego.

Przedmiotem ożywionej dyskusji stało się natomiast prawo gospodarcze i jego związek z prawem cywilnym. Zagadnienie relacji kodeksu cywilnego i ustawodawstwa gospodarczego (rozumianego jako ,przepisy normujące prawne formy

35 Dotyczy to także prac nad wcześniejszymi projektami kodeksu cywilnego z lat 1947-1948 (zob. J. Wasilkowski, Zagadnienie kodyfikacji jednolitego prawa cywilnego, „Demokratyczny Przegląd Prawniczy" 1947, nr 1-2, s. 62-64, który w szczegółach rozważa kształt przyszłego kodeksu cywilnego, nie wspominając ani razu nie tylko o prawie handlowym jako takim, ale nawet o wybranych zagadnieniach wchodzących w jego zakres) oraz z lat 1950-1952, już po zaostrzeniu kursu politycznego w Polsce (zob. A. Moszczyńska, Prace nad kodyfikacja majątkowego prawa cywilnego w latach 1950-52, „Miscellanea Historico-Iuridica” 2015, nr 2, s. 165 n.). Niemniej z potrzebą uchylenia kodeksu handlowego liczono się już od co najmniej 1951 r.; zob. ibidem, s. 173.

36 Zob. J. Wasilkowski, Zagadnienia..., s. 28, który uznawał, że powinno się mówić raczej o reformie prawa cywilnego niż o jego unifikacji. Proces ten został zrealizowany w ekstremalnie krótkim czasie siedemnastu miesięcy przez wydanie dziesięciu dekretów regulujących poszczególne dziedziny prawa cywilnego; zob. J. Wasilkowski, Zagadnienie..., s. 62; A. Lityński, Na drodze do kodyfikacji prawa cywilnego w Polsce Ludowej, [w:] Prawo wczoraj i dziś. Studia dedykowane Profesor Katarzynie Sójce-Zielińskiej, red. G. Bałtruszajtys, Warszawa 2000, s. 138; oraz J. Górska, Prace nad kodyfikacją i unifikacja prawa w Polsce po drugiej wojnie światowej, „Z Dziejów Prawa” 2019, nr 12, s. 654-655.

37 Zob. list J. Wasilkowskiego, przewodniczącego Komisji Kodyfikacyjnej, do wiceministra sprawiedliwości, w którym kodeks handlowy określa mianem „tworu ustawodawstwa burżuazyjnego", za: P. Fiedorczyk, Dylematy socjalistycznego kodyfikatora. Dokument archiwalny o pracach Komisji Kodyfikacyjnej w latach 1956-1958, „Miscellanea Historico-Iuridica” 2009, nr 8, s. 264; Komisja Kodyfikacyjna przy Ministrze Sprawiedliwości, Projekt Kodeksu cywilnego oraz przepisów wprowadzających Kodeks cywilny, Warszawa 1962, s. 187-188; M. Rybicki, Znaczenie kodyfikacji prawa cywilnego w okresie budowania socjalizmu. (Z przemówienia Ministra Sprawiedliwości na posiedzeniu Sejmu PRL w dn. 21.V.1963 r.), „Nowe Prawo” 1963, nr 6, s. 607-609, 617, który stwierdził, że kodeks cywilny ,uwalnia polski system prawny od balastu norm zupełnie anachronicznych”, wskazując na „niektóre przepisy o kupcu, o firmie, o zastawie rejestrowym rolnym i drzewnym, o lichwie pieniężnej”.

38 Zob. W. Czachórski, Przebieg..., s. 12; Komisja Kodyfikacyjna przy Ministrze Sprawiedliwości, Projekt..., s. 198, 212; A. Ohanowicz, Kodeks cywilny, „Ruch Prawniczy, Ekonomiczny i Socjologiczny" 1964, nr 4, s. 72-73, 79. 
działania socjalistycznych organizacji gospodarczych"39, do których zaliczano przedsiębiorstwa państwowe, organizacje spółdzielcze i kółka rolnicze) stanowiło jedną z podstawowych kwestii wymagających rozstrzygnięcia $\mathrm{w}$ toku prac nad nowym kodeksem ${ }^{40}$. Rozważano więc zasadność zaliczania prawa gospodarczego do obszaru prawa prywatnego w ogóle ${ }^{41}$, włączenia jego przepisów do kodeksu cywilnego ${ }^{42}$, a także zakresu takiej operacji (zasady jedności prawa cywilnego i zupełności kodeksu) ze względu na fakt, że funkcjonowanie socjalistycznych organizacji gospodarczych nie ograniczało się wyłącznie do sfery stosunków cywilnoprawnych, ale wchodziło też $\mathrm{w}$ sferę prawa pracy, prawa administracyjnego i finansowego ${ }^{43}$. W świetle doświadczeń politycznych z lat 1945-1956 wskazywano na przedwczesność ewentualnej kompleksowej kodyfikacji norm prawa gospodarczego, w szczególności w ramach kodeksu cywilnego, z uwagi na niedomknięcie, natenczas, zapoczątkowanych w 1956 roku przemian w zakresie zarządzania mieniem ogólnonarodowym (socjalistycznym) ${ }^{44}$. Co ciekawe, w dyskusji tej niejednoznacznie rysowała się nawet kwestia samego określenia „prawo gospodarcze" i zakresu tej dziedziny prawa ${ }^{45}$, której koncepcja została przejęta $\mathrm{z}$ radzieckiej nauki prawa ${ }^{46}$. Podnoszonym często problemem wykluczającym możliwość kompleksowego uregulowania problematyki socjalistycznych organizacji gospodarczych w nowym kodeksie cywilnym była zmienność regulacji ich form organizacyjnoprawnych oraz mnogość formuł ich współpracy gospodarczej. Szeroko dyskutowany był wreszcie tryb stanowienia norm dotyczących przedsiębiorstw państwowych, które w większości miały rangę podustawową (między innymi powstawały jako rozporządzenia i uchwały Rady Ministrów, rozporządzenia i zarządzenia poszczególnych ministrów ${ }^{47}$ ). Ostatecznie wszystkie te kwestie rozwiązano.

39 J. Wasilkowski, Kodeks cywilny PRL a zagadnienie prawa gospodarczego, „Państwo i Prawo" 1960, nr 3, s. 419. Pojęcie to, zaproponowane w projekcie, ostatecznie nie utrzymało się w uchwalonym kodeksie.

40 Zob. Komisja Kodyfikacyjna przy Ministrze Sprawiedliwości, Projekt..., s. 191.

41 J. Wasilkowski, Kodeks..., s. 413 n.; idem, Zagadnienia..., s. 31-33. Według autora istota sporu o prawo gospodarcze sprowadzała się do pytania o charakter prawny stosunków między przedsiębiorstwami państwowymi.

42 Zob. J. Wasilkowski, Zakres kodeksu cywilnego PRL, ,Nowe Prawo” 1957, nr 2, s. 5; A. Ohanowicz, Unifikacja i reforma prawa cywilnego, „Ruch Prawniczy, Ekonomiczny i Socjologiczny” 1959 , nr 3, s. 85.

43 Zob. S. Buczkowski, Problematyka obrotu uspołecznionego w kodeksie cywilnym, „Państwo i Prawo" 1964, nr 10, s. 479-481; S. Grzybowski, Koncepcja jedności prawa cywilnego na tle postanowień art. 2 i 384 k.c., „Studia Prawnicze” 1970, nr 26-27, s. 40, 48.

44 Zob. J. Wasilkowski, Kodeks..., s. 420, który wskazywał na stopniowy i „,w pewnym stopniu eksperymentalny" charakter tych przemian. Zob. też W. Czachórski, Przebieg..., s. 8-9, 19. Komisja Kodyfikacyjna przy Ministrze Sprawiedliwości, Projekt..., s. 190-193.

45 Zob. J. Wasilkowski, Kodeks..., s. 413-414, 417-420; W. Czachórski, Przebieg..., s. 19; S. Włodyka, Problem ,prawa gospodarczego”, „Studia Cywilistyczne” 5, 1964, s. 67 n.

46 Zob. więcej S. Grzybowski, [w:] System prawa cywilnego, t. 1, s. 53.

47 Zob. J. Wasilkowski, Kodeks..., s. 421 i powołane tam akty prawne. 
Przedostatni projekt kodeksu cywilnego w art. 1 stanowił, że reguluje on stosunki cywilnoprawne między osobami fizycznymi, między organizacjami zarówno socjalistycznymi, jak i niesocjalistycznymi, oraz między osobami fizycznymi a organizacjami (§ 1), przy czym w stosunkach między organizacjami państwowymi jego przepisy miały być stosowane tylko o tyle, o ile stosunki te nie były inaczej uregulowane przez ustawy szczególne oraz przez przepisy wydane przez właściwe organy naczelne administracji państwowej $(\S 2)$. O ile zgodnie z projektowanym art. $1 \S 1$ kodeks miał tworzyć podstawę regulacji wszelkich relacji cywilnoprawnych bez względu na charakter podmiotów w nie wchodzących, o tyle projektowany przepis art. $1 \S 2$ miał stanowić ,niezbędną korekturę przyjętej przez projekt koncepcji »jedności prawa cywilnego «"48. W uchwalonej zaś ostatecznie wersji art. 1 $\S 1$ k.c. stanowił, że kodeks reguluje stosunki cywilnoprawne między jednostkami gospodarki uspołecznionej, między osobami fizycznymi oraz między jednostkami gospodarki uspołecznionej a osobami fizycznymi. Wspomniana korekta jedności prawa cywilnego została natomiast złagodzona względem projektu, przybierając formułę art. 2 k.c., w myśl którego w wypadkach uzasadnionych szczególnymi potrzebami obrotu między jednostkami gospodarki uspołecznionej, Rada Ministrów lub upoważniony przez nią inny naczelny organ administracji państwowej mógł regulować stosunki tego obrotu w sposób odbiegający od przepisów kodeksu ${ }^{49}$.

$\mathrm{W}$ ten sposób domknięto rozdział w historii prawa handlowego, poddając nowy, socjalistyczny obrót gospodarczy regulacji kodeksu cywilnego i uchylając większość przepisów kodeksu handlowego. Szczęśliwie tylko pozostawione w mocy resztki jego unormowania, będące w hibernacji przez kolejne ćwierćwiecze, odegrały niepomierną rolę w reaktywacji prawa spółek (choć już nie samego prawa handlowego) po 1989 roku $^{50}$.

W kontekście tych rozważań na podkreślenie zasługują jednak dwie kwestie. Po pierwsze, uchwalenie kodeksu cywilnego i uchylenie kodeksu handlowego nie oznaczało zastąpienia przedwojennej kategorii kupca kategorią jednostki gospodarki uspołecznionej, tak samo jak regulacja prawa gospodarczego (prawa obrotu uspołecznionego), choćby włączona do kodeksu cywilnego, nie zastąpiła prawa handlowego. W obu przypadkach chodzi o całkowicie odmienne konstrukcje wyrosłe $\mathrm{z}$ różnych źródeł i uzasadnień. Jedynie miejsce i funkcja, jaką za sprawą historii obie kategorie miały w systemie prawa i obrocie gospodarczym, mogą skłaniać do pewnych, bardzo ostrożnych odniesień, z tym jednak zastrzeżeniem, że ani prawo gospodarcze w znaczeniu, jakie przydawano mu w okresie PRL, nie było spadkobiercą prawa handlowego, ani tym bardziej prawo handlowe nie jest wolnorynkową kontynuacją prawa gospodarczego ${ }^{51}$.

48 J. Wasilkowski, Kodeks..., s. 423.

49 Zob. A. Ohanowicz, Kodeks..., s. 72, który na tle tego przepisu uznał rozstrzygnięcie doktrynalnego sporu o zasadę jedności prawa cywilnego za mające charakter „raczej teoretyczny”.

50 A. Kappes, op. cit.

51 J. Frąckowiak, op. cit., s. 53, pisze o prawie obrotu uspołecznionego jako o „odpowiedniku prawa handlowego w warunkach gospodarki uspołecznionej”. 
Po drugie, wejście w życie kodeksu cywilnego miało usankcjonować w polskim porządku prawnym zasadę jedności prawa cywilnego, skutkując objęciem regulacją kodeksową również stosunków gospodarczych ${ }^{52}$. Oceniając to zdarzenie z dzisiejszej perspektywy, dodaje się, że przyjęcie owej zasady poskutkowało zniesieniem odrębności prawa handlowego jako formalnie samodzielnej gałęzi prawa. Mamy tu jednak do czynienia z dość dużym skrótem myślowym, mogącym wywoływać nieporozumienia ${ }^{53}$.

Sposób rozumienia zasady jedności prawa cywilnego od 1965 roku został bowiem zrewidowany wraz ze zmianami systemowymi po 1989 roku. W konsekwencji dzisiejsza jej treść jest odmienna od tej, którą przypisywali jej twórcy kodeksu cywilnego. Dla nich jedność prawa cywilnego wiązała się bowiem z problemem ujęcia w ramy kodeksu niejednorodnej, rozproszonej, niestabilnej, płynnej i wielowątkowej regulacji ówczesnego obrotu gospodarczego i jednostek gospodarki uspołecznionej. W latach pięćdziesiątych i sześćdziesiątych XX wie$\mathrm{ku}$ nie była to więc kwestia sposobu postąpienia z prawem handlowym, gdyż ono w tamtym czasie faktycznie już nie funkcjonowało i po prostu nie zaprzątało myśli kodyfikatorów (pozostawienie zachowanych w mocy przepisów kodeksu handlowego dotyczących spółek miało jeszcze inne uzasadnienie ${ }^{54}$ ). Współcześnie natomiast przez jedność prawa prywatnego rozumie się istnienie jednorodnej regulacji, która obejmuje zarówno obrót powszechny (prawo cywilne), jak i obrót profesjonalny (gospodarczy) i ustrój przedsiębiorców (tradycyjnie rozumiane prawo handlowe). Formalną zaś konsekwencją jedności prawa prywatnego jest dziś to, że prawo handlowe nie tworzy odrębnej gałęzi prawa prywatnego, ale jako część szeroko rozumianego prawa cywilnego składa się na jednolitą regulację prywatnoprawną ${ }^{55}$. O ile więc wraz z transformacją systemową sama zasada jedności prawa prywatnego ostała się jako spadek po epoce socjalizmu, o tyle w nowych warunkach ustrojowych i gospodarczych przypisano jej już nowe znaczenie, utrzymując mimochodem skutki degradacji prawa handlowego, które zostało sprowadzone do roli dyscypliny badawczej i dydaktycznej.

52 J. Wasilkowski, Metoda opracowania i założenia kodeksu cywilnego, „Państwo i Prawo” 1964, nr 5-6, s. 738-739.

53 Zob. np. M. Tarska, Jedność prawa cywilnego a regulacja prawna spółek handlowych zagadnienia wybrane, „Acta Iuris Stetinensis” 2019, nr 3, s. 193, która zauważa, że wprowadzeniu zasady jedności prawa cywilnego w 1965 r. nie towarzyszyło zapewnienie spójności między innymi przepisów kodeksu cywilnego i dotyczących spółek przepisów kodeksu handlowego.

54 Zob. S. Grzybowski, [w:] System prawa cywilnego, t. 3, cz. 2. Prawo zobowiazań. Część szczegółowa, red. S. Grzybowski, Wrocław 1976, s. 842, według którego pozostawienie w mocy części przepisów kodeksu handlowego stanowiło jedynie przejaw taktyki legislacyjnej ustawodawcy uzasadnionej przewidywaniem ich uchylenia w przyszłości.

55 Co do rozumienia zasady jedności prawa prywatnego zob. K. Kułak, Autonomia kodeksu spółek handlowych - między monizmem a dualizmem prawa prywatnego, „Przegląd Prawa i Administracji” 121, 2020, s. 30-31 i powołana tam literatura. 
Chociaż długie i bolesne lata 1945-1989 można uznać za zamknięty okres w historii Polski, z perspektywy prawa handlowego ma on swój trwający do dziś epilog. Najpierw przez blisko dwadzieścia lat (1945-1965) było ono niemym zakładnikiem nowego ustroju polityczno-gospodarczego. Obezwładnione na płaszczyźnie faktycznej przez wyeliminowanie jego koniecznego, osobowego i majątkowego zaplecza, przez lata dryfowało poza nurtem obrotu gospodarczego, umierając w zaaranżowanym przez ówczesną władzę zapomnieniu. Uchwalenie i wejście w życie kodeksu cywilnego — regulacji skądinąd zasługującej na uznanie i dziś - stanowiło jedynie ostatni akord przypieczętowujący los prawa handlowego jako samodzielnej, uporządkowanej gałęzi prawa prywatnego.

Kilkadziesiąt lat systemowego niebytu prawa handlowego przyniosło również zmianę podejścia tradycyjnej cywilistyki, która w tym czasie zaanektowała regulację obrotu gospodarczego ${ }^{56}$, sprowadzając znaczenie prawa handlowego do wyspecjalizowanej dziedziny prawa cywilnego. Podejście to zaczyna się powoli mścić na przejrzystości kodeksu cywilnego, od blisko 30 lat doraźnie uzupełnianego o kolejne, wymuszane dynamiką obrotu lub prawem unijnym, regulacje wchodzące w zakres prawa handlowego. Po 1989 roku zabrakło czasu i zrozumienia dla przywrócenia prawu handlowemu rangi, z której zostało odarte w poprzednim ustroju. Tym samym uprawnione jest stwierdzenie, że prawo handlowe zostało wskrzeszone jedynie połowicznie, nie odzyskawszy należnego mu, równorzędnego z prawem cywilnym miejsca w systemie prawa. Słusznie więc pisze J. Frąckowiak o ,powolnym i mozolnym” odbudowywaniu prawa handlowego ${ }^{57}$. Proces ten, jak się wydaje, jest wciąż w początkowym stadium.

\section{Bibliografia}

Bardach J., Leśnodorski B., Pietrzak M., Historia ustroju i prawa polskiego, Warszawa 2008.

Buczkowski S., Problematyka obrotu uspołecznionego w kodeksie cywilnym, „Państwo i Prawo” 1964, nr 10.

Czachórski W., Przebieg prac nad kodyfikacja prawa cywilnego PRL, „Studia Prawnicze” 1970, nr 26-27.

Encyklopedia praktyki prawniczej w dziesięciu tomach, cz. 1. Prawo handlowe, t. 1, red. A. Szczygielski, Warszawa 1938.

56 Zob. Z. Radwański, Kodyfikacja prawa cywilnego, „Ruch Prawniczy, Ekonomiczny i Socjologiczny” 2009, nr 2, s. 137, który dość pryncypialnie pisze o ,przejawianej niekiedy tęsknocie do odrębnego kodeksu handlowego - za tradycyjnym XIX-wiecznym wzorem", oraz o tym, że nazwa „kodeks” została nadana kodeksowi spółek handlowych „tylko po to, aby złagodzić opór zwolenników utrzymania dawnego Kodeksu handlowego z 1934 r.".

57 J. Frąckowiak, op. cit., s. 53. 
Fiedorczyk P., Dylematy socjalistycznego kodyfikatora. Dokument archiwalny o pracach Komisji Kodyfikacyjnej w latach 1956-1958, „Miscellanea Historico-Iuridica” 2009, nr 8.

Frąckowiak J., Osiemdziesiąt lat polskiego prawa handlowego - wzloty, upadki oraz mozolna reaktywacja, „Przegląd Prawa i Administracji” 101, 2015.

Górnicki L., Komisja Kodyfikacyjna II RP: pozycja ustrojowa, struktura organizacyjna, podejmowanie decyzji, „Prawo” 328, 2019.

Górnicki L., Organizacyjne zagadnienia kodyfikacji prawa handlowego w Komisji Kodyfikacyjnej RP (1919-1939), „Prawo” 285, 2003.

Górnicki L., Pogranicza systemów prawnych, w szczególności pozaborowych, w pracach nad kodyfikacjami prawa cywilnego i handlowego w II RP, „Prawo” 324, 2017, s. 149-150.

Górnicki L., Prace Komisji Kodyfikacyjnej RP nad kodeksem handlowym z 1934 r.: organizacja $i$ koncepcja kodyfikacyjna, „Przegląd Prawa Handlowego” 2015, nr 8.

Górnicki L., Przewodnie konstrukcje i pojęcia Kodeksu handlowego z 1934 roku, „Przegląd Prawa i Administracji” 101, 2015.

Górska J., Prace nad kodyfikacją i unifikacja prawa w Polsce po drugiej wojnie światowej, „Z Dziejów Prawa" 2019, nr 12.

Grzybowski S., Koncepcja jedności prawa cywilnego na tle postanowień art. 2 i 384 k.c., „Studia Prawnicze" 1970, nr 26-27.

Komisja Kodyfikacyjna przy Ministrze Sprawiedliwości, Projekt Kodeksu cywilnego oraz przepisów wprowadzajacych Kodeks cywilny, Warszawa 1961.

Kowalski P., O zaniechanej akcji likwidacji przedwojennych spótek prawa handlowego w Polsce Ludowej, „Miscellanea Historico-Iuridica” 2013, nr 12.

Kułak K., Autonomia kodeksu spótek handlowych - między monizmem a dualizmem prawa prywatnego, „Przegląd Prawa i Administracji” 121, 2020.

Lityński A., Na drodze do kodyfikacji prawa cywilnego w Polsce Ludowej, [w:] Prawo wczoraj i dziś. Studia dedykowane Profesor Katarzynie Sójce-Zielińskiej, red. G. Bałtruszajtys, Warszawa 2000.

Moszczyńska A., Prace nad kodyfikacją majątkowego prawa cywilnego w latach 1950-52, „Miscellanea Historico-Iuridica" 2015, nr 2.

Nazaruk P., Analiza historyczno-prawna rozwoju instytucji spótki z ograniczona odpowiedzialnościa w Europie Zachodniej i Polsce, „Studia Gdańskie. Wizje i rzeczywistość” 2014, nr 11.

Niedzielska-Jakubczyk D., Prawo handlowe przetrwało nawet socjalizm [wywiad z prof. A. Kappesem], „Gazeta Prawna” 29.04.2015.

Ohanowicz A., Kodeks cywilny, „Ruch Prawniczy, Ekonomiczny i Socjologiczny” 1964, nr 4.

Ohanowicz A., Unifikacja i reforma prawa cywilnego, „Ruch Prawniczy, Ekonomiczny i Socjologiczny" $1959, \mathrm{nr} 3$.

Prawo handlowe i gospodarcze II Rzeczypospolitej, red. R. Jastrzębski, Warszawa 2019.

Radwański Z., Kodyfikacja prawa cywilnego, „Ruch Prawniczy, Ekonomiczny i Socjologiczny” $2009, \mathrm{nr} 2$.

Rybicki M., Znaczenie kodyfikacji prawa cywilnego w okresie budowania socjalizmu. (Z przemówienia Ministra Sprawiedliwości na posiedzeniu Sejmu PRL w dn. 21.V.1963 r.), „Nowe Prawo” 1963, $\mathrm{nr} 6$.

Sołtysiński S., Kodeks spólek handlowych. (Podstawowe założenia), „Państwo i Prawo” 2000, nr 11. Sułkowski J., Polski kodeks handlowy, ,Ruch Prawniczy, Ekonomiczny i Socjologiczny” 1934, nr 2. System prawa cywilnego, t. 1. Część ogólna, red. S. Grzybowski, Wrocław 1974.

System prawa cywilnego, t. 3, cz. 2. Prawo zobowiąań. Część szczegółowa, red. S. Grzybowski, Wrocław 1976.

Tarska M., Jedność prawa cywilnego a regulacja prawna spótek handlowych — zagadnienia wybrane, „Acta Iuris Stetinensis” 2019, nr 3. 
Wasilkowski J., Kodeks cywilny PRL a zagadnienie prawa gospodarczego, „Państwo i Prawo” 1960, nr 3.

Wasilkowski J., Metoda opracowania i założenia kodeksu cywilnego, „Państwo i Prawo” 1964, nr 5-6.

Wasilkowski J., Zagadnienia kodyfikacji polskiego prawa cywilnego, „Nowe Drogi” 1960, nr 11.

Wasilkowski J., Zagadnienie kodyfikacji jednolitego prawa cywilnego, „Demokratyczny Przegląd Prawniczy" 1947, nr 1-2.

Wasilkowski J., Zakres kodeksu cywilnego PRL, „Nowe Prawo” 1957, $\mathrm{nr} 2$.

Włodyka S., Problem „prawa gospodarczego”, „Studia Cywilistyczne” 5, 1964.

Żabiński Z., Cywilno-prawne problemy spółek państwowo-prywatnych, „Przegląd Ustawodawstwa Gospodarczego" 1958, nr 6. 